the one to the other is unintelligible There are many diffculties connected with the subject of potential energy which the progress of science is likely to remove, but they are not to be got over by the verbal alteration proposed by your correspondent. The energy of compressed air was at one time supposed to be potenti:l and is now regarded as kinetic, Further inquiries into the constitution of matter may enable us to see that many forms of energy which are still regarded as potential are really "actual." Meanwhile we may, I think, suppose potential energy to mean the power of acquiring the power of doing work and to be located in the system possessing this power.

P. M.

The Arts Club, October 7

Indications of the Ice-age in Shetland

SHETLAND will now be narrowly searched for proofs of glacial action by every tourist who takes an interest in such vestiges of a bygone era. Smoothed surfaces, striæ, and grooves are so abundant and distinct on Mr. Peach's ground-the sand. stones on the shores of the Loch of Clickhemin, and of the immediately adjoining bay-as to havelong ago suggested the innocent or waggish notion that the last were scratches made by the prows of the Norsemen! Still on the mainland, but some forty miles distant, on the shores of the magnificent bay of St. Magnus, strix are to be seen on the sandstones of the banaf. fishing station at Stennis, and till, or boulder-clay, lies in patches on the Tuans of Hillswick. Ice has made oistinct markings, running east and west on the gneissose rock close by the door of the farm-house of Ailesburgh, which is perhaps abont a mile north of the narrow isthmus of Mavis-Grind, The buge moraine-looking mound, which lies between the south wast foot of Ronas-hill and the hearl of Ronas-voe, clains a special . xamination by those who wish to be further satisfied as to the former existence, or otherwise, of glaciai action in Shetland. G. G.

\section{The Discoverer of Photography}

IN your account of the death of Mr. Fox Talbot (NA'ruRE, vol. xvi. p. 464), you state that he first entertained the idea of the art of what is now called photography in 1833 , and that it was not till 1839 that he and Daguerre first made known the principles of photography under the name, I think, first of Daguerrotype, followed by Talbotype. I therefore think the following notes concerning Niepce may interest some of your readers :-

I cannot now from memory give exact dates, but $I$ think it was at least ten years previous to $\mathrm{I} 839$ that there lodged in a neigh bouring house to where I now reside a Frenchman of the name of Niepce ; he was, I think, engaged on a perpetual motion machine." He died, which necessitated his brother coming from Paris to Kew. The brother was a theatre scene painter, and had discovered the art of fixing upon metal the pictures of objects refected by the sun. On arriving at Kew he put up at the "Coach and I forses" Inn, then kept by Mr. Cusel, and not being able to speak English, Mr. Cusel introduced him to Mr. Francis Bauer, the celebrated botanical artist, then residing at Kew. Niepce had brought with him three pictures, specimens of his discovery, which he showed to Mr. Bauer, who became much interested in them. He deemed the discovery worthy of being made known to the Royal Society, but as the method of obtaining the pictures was not described in the notice sent to the Society, they would not entertain it, and nothing was done in the matter. Niepce returned to Paris, leaving two of the pictures with Mr. Bauer, and the third with Mr. Cusel in part payment of his bill, he being a poor man. Being a frequent visitor to $\mathrm{Mr}$. Bauer, the latter naturally called my attention to the two pictures that hung in his room for at least ten years. In time Niepce let the secret of his discovery become known to M. Daguerre, and in 1839 this discovery came before the public under the name of "Daguerreotype," and about the same time "Talbotype" was announced. This led Mr. Bater to write a letter to the Athencum, fully explaining all particulars of what I have here stated from memory. In his letter Mr. Bauer said he should be happy to show the pictures to those interested in the subject. Consequently he had many callers, one of the earliest being Dr. Percy, whom I remember coming to me, wanting to know where he could find Mr. Cusel, who had then retired and was living at Richmond. Dr. Percy went off to Richmond with the intention of buying the picture, but I remember telling him Mr. Cusel would not sell it as he was not in need of money. Such was the case, as Mr. Cusel told me some time after " that he would not sell it ; no! not if he was offered 1oo!. for it." Mr. Cusel is long since dearl, and what became of his picture I know not. After Mr. Bauer's death, in 1840 , these two pictures came into the possession of his friend, Mr. Robert Brown, and $I$ believe are now in the British Museum.

If you consider what $I$ have now stated worthy of a place in NATURE, it is at your service.

Park House, Kew, October 9

\section{The Portrait of Tycho Brahe}

IN reference to the portrait of Brabe engraved in NATURE (vol. xv. p. 406), and to Mr. Dreyer's remarks on it (vol. xv. p. 530), I have the pleasure of sending you the following particulars. In the first place I have permission from Herr Friis, of Copenhagen, the learned editor of Tichonis Braki et ad eum doctorum viroram Epistolce. Havnia, 1876 , \&c., to publish an important letter from himself :-

Copinhagen, June 9, 1877

Denr Sir,--I have seen in NAtruRE (vol. xv. p. 405) an article on Tycho Brahe, with a portrait of him after a painting in your possession. On that account I take the liberty of addressing myself to you.

In a book printed in Copenhagen in the year 1668 is mentioned a portrait of Tycbo Brahe which once belonged to King Frederick III, and which, no doubt, has had an ernblematic figure and inscription similar to that of the portrait you own. The title of this book is "Inscriptiones Haffnienses latinæ, danicx et germanicæ una cum inscriptionibus Amagriensibus, Urani. burgicis et Stellaburgicis, \&c., edi curavit Petrus Johannis Resenius," and in that you read at page 335 the following:-

"Sub pyramide tegumento quodam cooperta ad effigiem ejus qux in Augustissimi Regis Daniæ Friderici III. Bibliotheca hodie reservatur depicta hac legitur inscriptio :-

S'TANS TEGOR IN SOLIDO VENTUS IREMAT IGNIS ET. UNDA VANDESBECHI

AN. MDXCVII QUO POST DIVTINUM IN PATRIA EXILIUM DEMUM PRISTINE LIBERTATI RESTITUTUS FUI TYCHO BRAHL, OT.

On leaving Denmark 'T. Brahe sent his portrait to his friend, the learned Holger Rosenkrantz. This has, $\mathbf{I}$ suppose, been one resembling the one you now possess, even if it should not be just the same. Compare T. Brabe, "Astronomia instaurata mechanica." Wandesburgi, 1598, fol 4.

The German letters on the order M. H.Z. G. A. indicate Frederick the Second's motto : My hope (is) in God alone (Maine Hoffnung $z a$ Gott allein), which is often seen in buildings, \&c., from his time.

If you will be kind enough to send me a photograph of the before-mentioned portrait, I should feel very grateful to you, as $I$ have made the biography of $T$. Brahe my special study, and just recently began to publish his correspondence with his learned contemporaries.

Hoping that you will not deny me this favour, I am, dear sir, Yours obediently

\section{Cortadelers Gade, 7, Copenhagen}

F. R, FRIS

I have referred to an exquisite copy of the Inscriptiones Haftinienses, from the library of Colbert, belonging to Chetham's Library, in this city, and on the same page referred to by Herr Friis I find a poem by Oliger Rosenkrantz addressed to T. Brahe, and prefixed to the Mechanica, of which the last two lines are very interesting, as alluding, in my opinion, to the emblem on my portrait. They are :-

"Pectora quam Divi dispensant tramite justo, Stansq. audo Auctus, imbres et flumina temne."

I wish to add a few remarks, and before I proceed farther I would observe that in your engraving the dress of Brahe is not given correctly, not from any fault of yours or of your engraver, but because the detailed drawings sent in answer to a request from him to me for details did not reach him until the plate was too far advanced. I have had the picture re-photographed, the photograph worked upon from the picture in a strong light, and a satisfactory result will be published in the Memoirs of the Literary and Philosophical Society of Manchester, and also, I believe, in Herr Friis's very interesting and important work, two fasciculi of which he has kindly sent me. 